\title{
TRANSLATING EUROPEAN LABOR RELATIONS \\ PRACTICES TO THE UNITED STATES THROUGH \\ GLOBAL FRAMEWORK AGREEMENTS? GERMAN AND SWEDISH MULTINATIONALS COMPARED
}

\author{
MARKUS O. HELFEN, ELKE SCHÜßLER, AND DIMITRIS STEVIS*
}

\begin{abstract}
Extensive research has shown that European multinational enterprises (MNEs) have a propensity to avoid collective employee representation when going abroad. This study investigates whether Global Framework Agreements (GFAs) can reverse this pattern by comparing how four European MNEs-two from Germany and two from Sweden-implement GFAs in the United States, a country with weak collective representation rights. The authors find that an MNE's home country labor relations (LR) system mediates whether GFAs support collective representation in the United States. Sweden's monistic LR system, in which unions are the dominant organizations legally representing workers, gives unions the power to directly influence the negotiation and implementation of GFAs. By contrast, Germany's dualistic LR system, in which unions and works councils share worker representation, weakens the influence of unions on implementing the GFA. MNEs' home country LR systems thus influence how transnational instruments are used to improve collective representation in host countries.
\end{abstract}

Am I adopting European-based policies and introducing them to the U.S.? The answer is no.

RubberCorpDE US subsidiary management

\footnotetext{
* Markus O. Helfen is a Senior Research Fellow and Designate Visiting Professor of Human Resource Management and Employment Relations at Freie Universität Berlin. Elke Schüßler is an Assistant Professor of Organization Theory at Freie Universität Berlin. Dimitris STEvis is a Professor of International Politics at Colorado State University, Fort Collins. We thank the associate editor, Paul Marginson, and three anonymous reviewers for their valuable feedback on improving this article. We presented previous versions of this article at the Academy of Management International Business Division 2012 and at internal research seminars at Freie Universität Berlin und Grenoble Ecole de Management. We are particularly indebted to Mike Fichter, Stephen Frenkel, Gregory Jackson, Jörg Sydow, and Miriam Wilhelm for helpful comments in the development of this article. Additional results and material used to generate the results presented in the article are available from the author(s) at Dimitris.Stevis@ColoState.edu.
}

KEYWORDs: transfer of labor relations practices, HRM, ILO standards, collective representation, Global Framework Agreements, CSR

ILR Review, 69(3), May 2016, pp. 631-655

DOI: 10.1177/0019793915624090. (C) The Author(s) 2016

Journal website: ilr.sagepub.com

Reprints and permissions: sagepub.com/journalsPermissions.nav 
$\mathrm{R}$ esponding to rising concerns about weak compliance with labor standards in global value chains, innovative transnational regulations such as Global Framework Agreements (GFAs) have been created to spread workers' rights, particularly the right to unionize and bargain collectively, across the production locations of multinational enterprises (MNEs). GFAs were developed by Global Union Federations (GUFs) and pose a challenge to unilateral approaches toward labor relations (LR) norms because they hold signatory MNEs directly responsible for adhering to core labor standards as defined by the International Labour Organization (ILO) (Papadakis 2011). Although such global instruments typically target developing countries, the experience with GFAs shows that enacting freedom of association and the right to collective bargaining effectively is also problematic in the United States (Fichter and Stevis 2013). Studying whether GFAs are able to influence LR practices in the U.S. subsidiaries of signatory MNEs is thus critical for our understanding of the possibility of diffusing workers' rights across the globe (Fichter, Stevis, and Helfen 2012). For U.S. LR, GFAs constitute a possibility to counteract the domestic curtailing of labor rights (Compa 2008, 2012).

Studies on the transfer of collective representation practices have shown that U.S. MNEs tend to adopt union avoidance strategies in European countries with strong statutory support for collective representation (e.g., Müller 1998; Müller-Camen et al. 2001). Conversely, European MNEs lean toward adapting to the more voluntaristic LR practices prevailing in the United States (e.g., Cooke 2001; Human Rights Watch 2010). Yet the exact interplay of institutions, interests, and identities of actors in such transfer settings needs to be further examined (Dörrenbächer and Geppert 2011; Geppert and Dörrenbächer 2014). The way in which actors draw on transnational institutions to influence the dynamics of transfer constitutes a particularly promising new area of research in this context (Djelic and Quack 2003; Tempel and Walgenbach 2007).

This study compares four MNEs from two European countries and examines how they translate the collective representation practices inscribed in GFAs into their U.S. subsidiaries. We find that the monistic, union-based system of labor representation in Sweden equipped labor actors with more opportunities to translate collective representation practices to the United States than did the dualistic German system. ${ }^{1}$ Swedish unions regarded the GFA as an instrument to move beyond existing corporate social responsibility practices and used direct influence over headquarters (HQ) management to negotiate comparatively stronger GFAs and to enforce this commitment through

\footnotetext{
${ }^{1}$ German LR are characterized by a duality of employee representation-that is, representation is formally separated in unions and union-independent works councils. By law, the German works council is elected by workers and is obliged to honor the best interest of employees and the firm in exerting its codetermination rights. Firms are obliged to bear the administrative costs of works council elections and operations. Sweden has a monistic system in which unions represent workers from the shop floor up to the board level.
} 
collaboration with U.S. unions and GUFs. By contrast, HQ management in the German cases was able to subsume GFAs under existing CSR policies by negotiating GFAs with those labor actors that accepted management prerogative and by marginalizing the role of GUFs. We interpret these qualitative findings as indicating that the difference between monistic and dualistic LR systems is relevant for understanding the institutional and micro-political dynamics around GFAs or other transnational instruments of labor regulation.

\section{Politics and Institutions in the Transfer of LR Practices from and to the United States}

Studies in a neo-institutionalist tradition attribute problems with transferring MNE management practices cross-nationally to a high cognitive, normative, and regulative institutional distance between home and host countries that expose subsidiaries to conflicting demands for internal and external legitimacy (Kostova 1999). Similarly, comparative institutional analyses (e.g., Hall and Soskice 2001) stress that particular institutional configurations in MNE home countries, broadly classified as liberal and coordinated market economies, shape transfer patterns. Going beyond these structural arguments, detailed case studies reveal that transfer outcomes vary among sectors, firms, or specific practices because each context provides different incentives and opportunities for supporting or resisting the transfer process (e.g., Pries 2003; Dörrenbächer and Geppert 2006; Brewster, Wood, and Brookes 2008; Meardi et al. 2009). Micro-political aspects are considered as particularly prominent in the transfer of LR because of the institutionalized interest conflicts between management and labor actors (Ferner 1997; Ferner, Almond, and Colling 2005; Geppert and Williams 2006; Morgan and Kristensen 2006; Edwards, Colling, and Ferner 2007; Ferner, Edwards, and Temple 2012; Edwards, Marginson, and Ferner 2013; Edwards, Tregaskis et al. 2013).

United States multinationals that come to Europe, for instance, are said to transfer a unilateral HRM model characterized by nonunionism as a standardized "best practice" (Pudelko and Harzing 2007), but they are potentially constrained by existing collective LR in local subsidiaries (Ferner, Almond, Colling, and Edwards 2005). These constraints are stronger in manufacturing than in service-sector firms (Tempel et al. 2006) and are tolerated more in countries with enterprise-based rather than sectoral representation systems (Royle 1998; Colling, Gunnigle, Quintanilla, and Tempel 2006). Conversely, MNEs from coordinated market economies such as Germany are expected to leave LR practices to the discretion of local management when they go abroad (Ferner, Quintanilla, and Varul 2001), sometimes even strategically using subsidiaries for reverse diffusion of AngloSaxon practices (Ferner and Varul 2000). 
Compared with the vast amount of research on German-, Japanese-, British-, and U.S.-based MNEs, there is less but growing evidence on the transfer patterns in Scandinavian MNEs. In early international business research, Hedlund (1981) pointed to a weak influence of Swedish HQ on global operations because of an informal management style and a lack of formal planning in Swedish MNEs. Relying on a case study of a Swedish high-tech MNE, Hayden and Edwards (2001) showed that this participatory management style was transferred to foreign subsidiaries while at the same time Anglo-Saxon-type performance pay systems were introduced. Rolfsen (2013) demonstrated that a Norwegian MNE transferred partnership practices to its French-Canadian subsidiaries, i.e., to a host country with typically more adversarial labor relations than Norway, arguing that partnership was fundamental to the firm's business model.

On the basis of this literature one would expect that European firms have the capacity to transfer collective representation practices to their U.S. subsidiaries but may not choose to do so in practice, even though most commit themselves to support freedom of association and collective bargaining principles in their home operations. In the United States, foreign firms can easily operate as nonunion entities because the U.S. labor law system allows the adoption of state-level right-to-work laws that complicate union representation in the workplace (Katz and Colvin 2011; Hegji 2012). However, this conjecture requires further elaboration in the context of new transnational instruments such as GFAs that support the spread of collective representation by formally empowering labor representatives as a driver of transfer processes.

\section{Global Framework Agreements and the Transfer of Collective Representation Practices}

Following the ILO's 1998 Declaration of Fundamental Rights and the ILO's strategic focus on five core labor standards from among all ILO conventions (International Labour Office 2002), GFAs concentrate mainly on employees' right to organize and bargain collectively, nondiscrimination, and the prohibition of child and forced labor. To date more than 100 GFAs have been signed, currently mostly by European MNEs (European Commission 2015). GFAs are formally cosigned by GUFs, industry-wide international federations of unions representing millions of workers from dozens of countries (Stevis and Boswell 2008). Home country unions, influential works councils, or European Works Councils (EWCs) often lead GFA negotiations (e.g., Helfen and Sydow 2013), a development that indicates complex micro-political actor constellations.

Existing research indicates that MNEs can leave the enforcement of the GFA to the discretion of local actors, undermining their effectiveness, especially in highly decentralized and fragmented value chains (Davies et al. 2011; Riisgaard and Hammer 2011). In other cases, as in the unfolding 
situation at the Volkswagen plant in Chattanooga, Tennessee, GFAs do effect a transfer of collective representation practices, but this effort is heavily constrained by resistance from local politics (Compa 2014).

Thus, bringing a GFA to bear in local conditions is often less a matter of directly transferring particular institutions, such as German works councils, to the United States than a matter of "translating" (Sahlin-Andersson and Engwall 2002) freedom of association and collective bargaining principles into a local context. In our setting, one form of translating would be the adoption of a sustained dialogue between host country management and unions and engagement in joint information and monitoring activities, even when these are not accompanied by unionization or collective bargaining. A second, stronger form of translating is the adoption of "positive neutrality," whereby the U.S. subsidiary does not raise obstacles to union campaigns and actively communicates to its employees that joining a union is acceptable. The continuation of unionization in the event of an acquisition would also be a form of translation as companies often use acquisitions to weaken unions. Translation might be hampered by subtle forms of MNE opposition such as tolerating informal union-avoidance strategies or preventing union access to employees at the workplace (Compa and Feinstein 2012).

\section{Research Setting and Methodology}

\section{Comparative Case Study Design}

The MNEs

We have selected four cases for systematic comparative analysis, dubbed PapCorpSE, ConCorpSE, BuildCorpDE, and RubberCorpDE, from a larger sample of 22 GFAs signed by European companies that we analyzed between 2008 and 2011 (for an overview see Sydow et al. 2014). Given the relative novelty of GFAs and our aim to untangle institutional and micropolitical dynamics, we followed a qualitative approach. We selected our cases depending on their country of origin-Germany (DE) or Sweden (SE) - because MNEs from these countries were among the first movers in the adoption of GFAs and both have strong but varying LR systems. Our cases also come from two sectors: PapCorpSE and RubberCorpDE are mainly producers of consumer and industrial goods, whereas ConCorpSE and BuildCorpDE operate in the construction industry. Our design therefore includes one German and one Swedish MNE in each of two sectors (see Table 1).

We control for one host country setting, the United States. All the companies have accelerated their presence in the United States during the last 15 years largely through acquisitions and are present in different states with different labor laws. RubberCorpDE has the most facilities in the United States, while PapCorpSE has the fewest. PapCorpSE has globally integrated product divisions, and ConCorpSE runs decentralized but also globally 


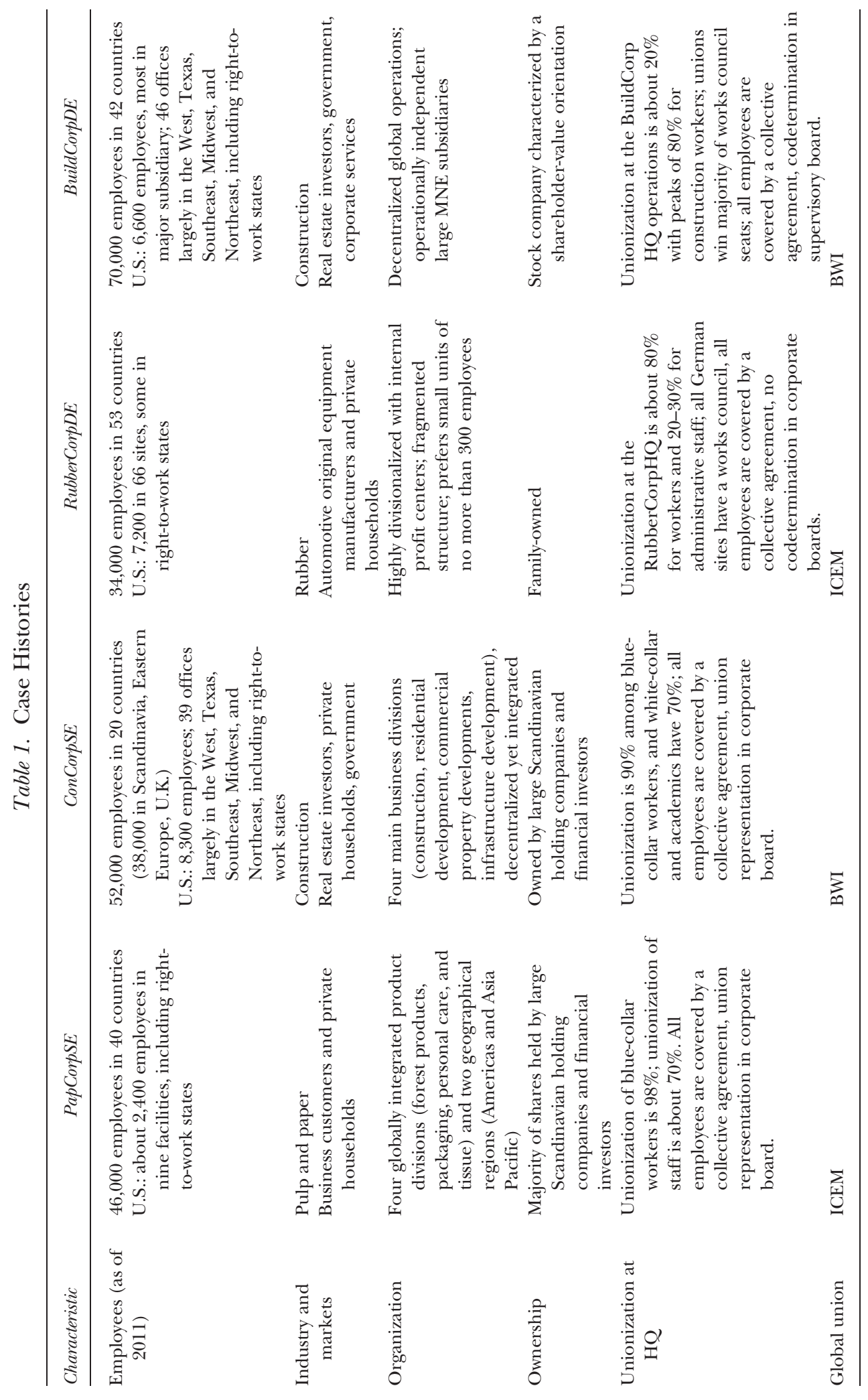


integrated divisions. Both German firms have decentralized product divisions; however, RubberCorpDE exercises strong central influence over its divisions through capital investments. The two construction companies are very similar in terms of size and operations and tend to hire union labor in locations where unions are strong and nonunion labor where they are weak. Both focus on large projects, which tend to be more unionized than residential projects (Cooper 2012).

\section{Home Country Labor Relations}

The selected German and Swedish MNEs exemplify Western European collective labor representation, which is characterized by comparatively high levels of coverage through industry-wide collective bargaining, union representation in corporate boards, and consultation through works and union councils (Jackson and Deeg 2008). Although Sweden shows signs of change in its overall business systems, its LR institutions remain rooted in the country's rather strong social democratic tradition (Pontusson 1997). Most notably, Sweden shows higher union densities and collective bargaining coverage than Germany (Schmitt and Mitukiewicz 2012). In 2008, unionization in Sweden stood at $68 \%$ and collective bargaining coverage at around $90 \%$ of the dependent workforce, whereas in Germany unionization is close to $20 \%$ and collective bargaining coverage (including firm-level agreements) is about 60\% (European Commission 2013: 23).

The Swedish and the German LR systems also diverge significantly regarding the role of trade unions. In Germany, trade unions are responsible for collective bargaining at the sectoral and firm level, whereas works councils are responsible for codetermination in the workplace and have a say on issues such as dismissals, work organization, and restructuring (Thelen 1993; Frege 2003). In Sweden, trade unions represent workers from the workplace to the industry level, and local union bodies also form the backbone of company codetermination (Brulin 1995; Kjelberg 1998; Nergaard et al. 2009; Ilsoe 2012). A dualistic system like the German one provides workers with an added layer of representation, but it can also engender conflicting dynamics between unions and works councils because the latter are legally obliged to act in the interest of the workers and the company but are not obliged to be union members (Behrens 2009).

\section{Host Country Labor Relations}

For U.S. unions, the primary goal of having GFAs is to support them in getting recognition and collective bargaining. In unionized firms, employees enjoy legal standing based on the National Labor Relations Act (1935), but these rights were significantly limited in subsequent periods (e.g., TaftHartley Act of 1947). Multiemployer agreements and pattern bargainingcommon during the post-World War II era-have become rare (Katz 1993; Eaton and Kriesky 1998). Even firm-level collective agreements are difficult 
to negotiate because frequently several unions claim jurisdiction. Additionally, unions fear that the conflict resolution system-organized around the National Labor Relations Board (NLRB)—works to the advantage of management (Shimabukuro 2012). In combination, the antiunion sentiment of business and of political elites at the national and state levels and a weak collective labor law create a formidable challenge to collective worker representation (Bronfenbrenner 2009; Marens 2012; Wessels 2013; Hogler 2015). A senior union official aptly captured this challenge:

The [United States is] unique when it comes to the situation of GFAs, because the management always claims that the United States is a unique market. . . . And of course they don't want to have the European trade union tradition spilling over through a GFA. (ConCorpSE union at HQ)

\section{Global Union Federations}

GUFs depend on the strength of their respective affiliates. For GUFs, GFAs are one of the main instruments to engage with global labor regulation because they legitimize GUFs' role as interlocutors for MNEs at the transnational level. The MNEs in our study deal with two GUFs: the International Federation of Chemical, Energy, Mine and General Workers' Unions (ICEM-now IndustriAll) and the Building and Wood Workers' International (BWI). Together, the $\mathrm{ICEM}^{2}$ (16 GFAs) and the BWI (19) accounted for a good third of all GFAs signed up until 2013. When it became part of IndustriAll, the ICEM had 20 million members unionized in 467 affiliated unions in 132 countries (Platzer and Müller 2011). The ICEM took a pronounced social partnership or "pragmatic international solidarity" approach to GFAs, strengthening ongoing social dialogue (ICEM 2010). BWI operates in construction, building materials, and woodworking industries with 12 million members organized in 318 national affiliates from 130 countries. The BWI has sought to engage with management collaboratively in the context of GFAs-for example, by focusing on issues of health and safety (e.g., Hellmann 2007).

\section{Data Collection and Analysis}

We collected and analyzed qualitative data from a variety of sources (see Table 2).

\section{Interviews}

We conducted 41 interviews, of which 17 were with labor and management representatives at the MNE HQ level, and 13 were in U.S. subsidiaries. In

\footnotetext{
${ }^{2}$ The ICEM is now part of IndustriAll global union, founded on June 19, 2012 (http:/ /www.industriallunion.org).
} 
Table 2. Case Study Database

\begin{tabular}{|c|c|c|c|}
\hline Company & Interviews & Dates conducted & Length \\
\hline \multicolumn{4}{|l|}{ Case-specific data } \\
\hline \multirow[t]{7}{*}{ BuildCorpDE } & HQ management (1) & $5 / 8 / 09$ & 43 min. (phone) \\
\hline & HQ labor representatives (5) & & \\
\hline & - Works council board representative & $6 / 17 / 09$ & 23 min. (phone) \\
\hline & - Works council & $7 / 3 / 09$ & 27 min. (phone) \\
\hline & $\begin{array}{l}\text { - Union negotiator, international } \\
\text { secretary }\end{array}$ & $7 / 9 / 09$ & 56 min. (phone) \\
\hline & - Union representative & $1 / 19 / 11$ & 89 min. (person) \\
\hline & $\begin{array}{l}\text { - Union representative in supervisory } \\
\text { board }\end{array}$ & $3 / 2 / 15$ & 30 min. (phone) \\
\hline \multirow[t]{6}{*}{ ConCorpSE } & HQ management (1) & $8 / 27 / 10$ & 47 min. (phone) \\
\hline & HQ union representative (2) & $10 / 1 / 09$ & 67 min. (phone) \\
\hline & & $3 / 19 / 15$ & 46 min. (phone) \\
\hline & GUF representative (1) & $10 / 25 / 11$ & 44 min. (phone) \\
\hline & U.S. management & $8 / 19 / 11$ & written comments \\
\hline & & $9 / 7 / 11$ & written comments \\
\hline \multirow{8}{*}{$\begin{array}{l}\text { Joint material } \\
\qquad \text { BuildCorpDE } \\
\text { and } \\
\text { ConCorpSE }\end{array}$} & GUF representative (2) & $5 / 19 / 09$ & 49 min. (person) \\
\hline & & $2 / 23 / 11$ & 65 min. (person) \\
\hline & U.S. labor representatives (5) & & \\
\hline & - Head of international affairs & $7 / 22 / 09$ & 74 min. (in person) \\
\hline & & $2 / 11 / 11$ & 92 min. (in person) \\
\hline & & $10 / 4 / 12$ & $60 \mathrm{~min}$. (phone) \\
\hline & - State-level union leader & $10 / 31 / 12$ & 73 min. (phone) \\
\hline & $\begin{array}{l}\text { - National union leader, US GUF } \\
\text { representative }\end{array}$ & $1 / 31 / 13$ & 67 min. (phone) \\
\hline \multirow[t]{11}{*}{ PapCorpSE } & HQ management (1) & $2 / 11 / 11$ & 51 min. (phone) \\
\hline & HQ labor representative (2) & $1 / 27 / 11$ & 39 min. (phone) \\
\hline & & $3 / 5 / 15$ & 33 min. (phone) \\
\hline & GUF representatives (2) & & \\
\hline & - Negotiation representative & $5 / 18 / 09$ & 54 min. (in person) \\
\hline & - Industry officer & $12 / 15 / 10$ & 70 min. (phone) \\
\hline & U.S. labor representatives (5) & & \\
\hline & $\begin{array}{l}\text { - Head of national organizing } \\
\text { - Head of sectoral organizing }\end{array}$ & $\begin{array}{l}8 / 11 / 10 \\
\text { (joint interview) }\end{array}$ & 44 min. (phone) \\
\hline & $\begin{array}{l}\text { - National union staff, international } \\
\text { affairs }\end{array}$ & $11 / 20 / 10$ & 112 min. (phone) \\
\hline & - Head of international affairs & $9 / 27 / 12$ & 60 min. (phone) \\
\hline & $\begin{array}{l}\text { - Head of relevant sector and } \\
\text { responsible relations to } \\
\text { PaperCorpSE }\end{array}$ & $4 / 27 / 15$ & 55 min. (phone) \\
\hline \multirow[t]{14}{*}{ RubberCorpDE } & HQ management (2) & & \\
\hline & - Head of division & $11 / 26 / 08$ & 30 min. (phone) \\
\hline & - VP HRM & $8 / 18 / 09$ & 41 min. (phone) \\
\hline & HQ labor representatives (3) & & \\
\hline & - Union representative & $6 / 13 / 09$ & 78 min. (person) \\
\hline & - Head of (European) works council & $6 / 19 / 09$ & 46 min. (phone) \\
\hline & & $2 / 19 / 15$ & 45 min. (phone) \\
\hline & GUF representatives (2) & & \\
\hline & - Industry officer & $6 / 30 / 09$ & 50 min. (phone) \\
\hline & - GUF president & $7 / 16 / 09$ & 39 min. (phone) \\
\hline & U.S. management (1) & $9 / 30 / 10$ & 38 min. (person) \\
\hline & U.S. labor representatives (2) & & \\
\hline & - National union leader & $10 / 19 / 10$ & 35 min. (phone) \\
\hline & - Local organizer & $11 / 1 / 10$ & 30 min. (phone) \\
\hline
\end{tabular}


Table 2. Continued

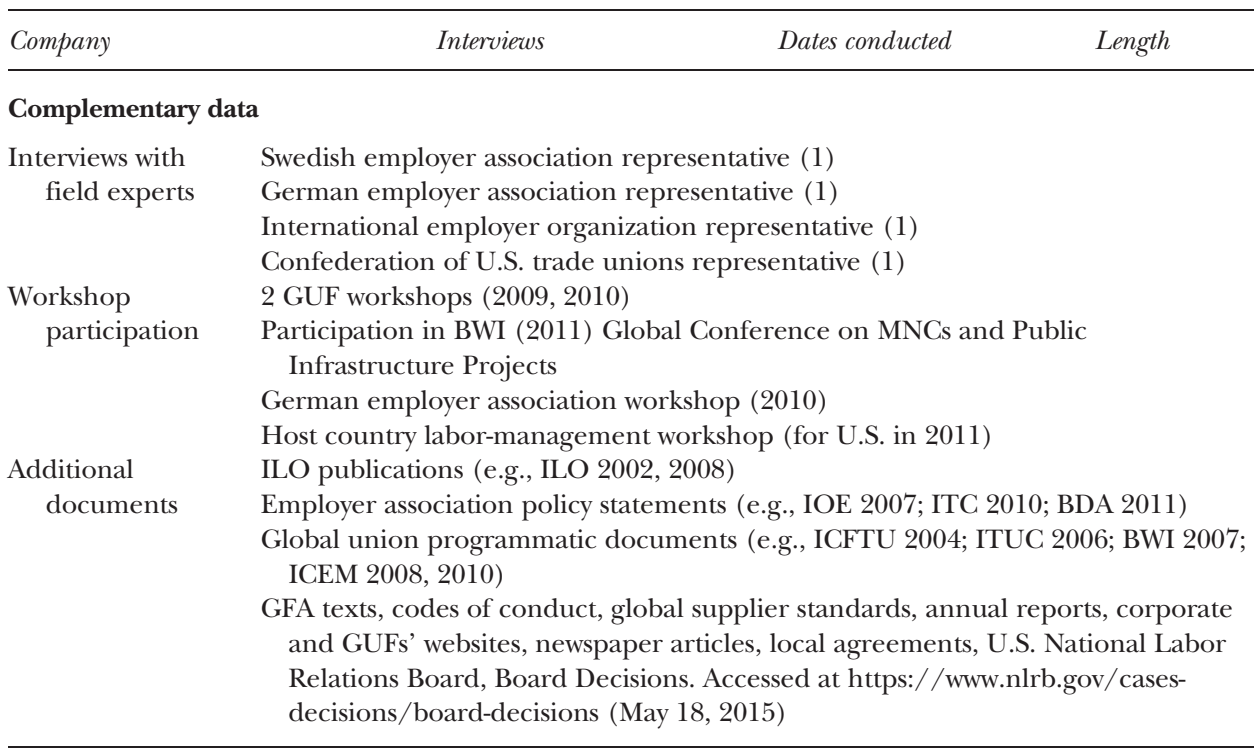

the United States we talked to unions that have organized one or more sites of the respective companies. On the management side we usually had interviews with $\mathrm{HR}$ managers, but we were not able to get access to local management in two of our cases. In addition, we interviewed seven GUF representatives responsible for the respective MNEs. These officers usually aggregate the experiences of the involved affiliates and are key informants on corporate strategies beyond single countries and MNEs. We also interviewed four field experts for background information on the three countries' LR.

Interviews addressed the overall CSR policy of the company, the role and tradition of labor relations, and the GFA process. We also asked unions about their international division of labor and their assessment of GFAs as a tool for changing LR. The identification of instances of conflict, such as in local approaches to union recognition, was particularly challenging. We therefore relied on a multi-source strategy using interview as well as archival data.

\section{Complementary Data}

To gain more insights on U.S. practices we sought and received specific information from host country and global unionists. One unionist, for instance, provided us with the neutrality agreement between PapCorpSE and the U.S. union as well as detailed data on locations and employment of the various plants. Another provided us with copies of exchanges between U.S. unions, GUFs, and management in the ConCorpSE case. We have video footage of a RubberCorpDE subsidiary manager demanding that union organizers leave the premises of a targeted plant. We examined Department of Labor and NLRB databases on collective agreements and labor disputes. An intensive review of trade journals, local business news 
media, local government websites, and national and local union websites provided us with additional information on the various subsidiaries. We also participated in several workshops.

\section{Analytical Process}

We started our analysis by comparing the GFAs' substantive regulations and what they prescribe in terms of implementation-that is, the scope of coverage as well as rules for information, monitoring, and conflict escalation. Then we examined actual instances of conflict resolution and monitoring to assess the GFAs' impact on collective representation practices in the United States.

\section{Findings}

\section{GFA Negotiation}

\section{Management Interests}

The GFAs we examined belong to the group of first-generation GFAs signed between 2000 and 2004, with RubberCorpDE and BuildCorpDE signing as early as 2000. Although managerial support varied, all MNEs considered signing a GFA a useful tool for corporate responsibility.

Both Swedish MNEs were explicitly concerned about employees as important stakeholders, with PapCorpSE stressing that responsible corporate behavior had already been "in our blood" (PapCorpSE HR manager). The German MNEs, in contrast, were mainly concerned about their public image. RubberCorpDE HR management explained that "shareholders do not want to be ashamed of their corporation" and emphasized the owner family's responsibility. Yet the company was skeptical about a GFA, highlighting the huge economic, social, and legal differences between national labor markets and between ILO conventions and national labor laws. As the owner stated, "We did not promise anything in the GFA beyond what we are already doing." BuildCorpDE welcomed the GFA as an opportunity to keep alleged violations of labor standards an internal affair and to legitimize self-imposed obligations and CSR initiatives.

\section{MNE Labor Relations}

The underlying labor relations help explain the different attitudes of the four MNEs examined here. PapCorpSE and ConCorpSE both have a history of cooperative relations and open dialogue with unions in their home market, with unionization rates well above the already high Swedish average. PapCorpSE's home union is strongly involved in corporate decision making and was able to veto a code of conduct drafted by the company in 2003:

I know there was tension within the company with representatives from the United States, they wanted this wording in this code of conduct. So we said no, 
we will not accept this, but if you conclude a Framework Agreement with us where we can close the door on union busting we will accept this code of conduct. (PapCorpSE union at HQ)

ConCorpSE management and labor representatives also stress the history of a trust-based, social partnership approach in Scandinavia, though not necessarily in other regions. Similar to PapCorpSE, the Swedish union, collaborating with the BWI and the EWC, was responsible for negotiating the GFA and securing a strong commitment by management to labor standards, which later included the development of a global health and safety strategy.

The German BuildCorpDE is engaged in a permanent dialogue with unions but one largely restricted to its core business units in Germany, where either the workforce is highly unionized or unions can benefit from other institutionalized power resources such as works councils or BuildCorpDE's social partnership tradition. The GFA was initiated by the head of the national union, who sits on the supervisory board. However, the agreement was considered a continuation of LR at BuildCorpDE, which are characterized by an informal ad hoc approach in dealing with problems as they occur:

Binding standards, a negotiation body-we don't have such things, this is not how we work. We have guidelines, they are published internally, everybody knows them. ... If there are problems, we have ways of dealing with them. (BuildCorpDE works council supervisory board representative at HQ)

The GFA, in the words of this representative, was not negotiated by GUFs, but the BWI's standard template was internally adapted in informal talks "without any red tape."

RubberCorpDE is more skeptical about union involvement in corporate governance bodies but applies industry-wide collective bargaining and is confronted with an influential works council that draws legitimacy from a highly unionized workforce in HQ manufacturing operations:

We prefer to talk to our people directly instead of through institutions. . . That doesn't mean that we do not accept unions at the table, but we have a problem with unions monopolizing communication. (RubberCorp HQ management)

The GFA was initiated by the head of the works council, also head of the EWC, who had been actively collaborating with representatives from ICEM and U.S. unions. However, management shifted toward negotiating with the national union (as representing the ICEM), and after a two-year period, the result was a much weaker agreement than originally envisioned by the works councilor:

We wanted to be much more specific on sanction mechanisms and escalation procedures in cases of violations. At the end, these things were left unspecified, because the ICEM and [union] thought it would be better to have a weak 
agreement than no agreement. (RubberCorp head of works council at HQ and of EWC)

The national union representative commented on this process: "The works council clearly must have felt thwarted" (RubberCorpDE union representative at HQ).

\section{GFA Content}

The GFAs differ in the way substantive rules are stated as well as on scope and procedural rules.

\section{Substantive Rules}

All GFAs include core ILO conventions such as employees' right to organize, collective bargaining, prohibition of child or forced labor, and nondiscrimination. The PapCorpSE's agreement details labor standards as fundamental human rights. For example,

[PapCorpSE] recognizes the fundamental right of every employee to decide on whether or not to be represented by a recognized trade union of their choice. [The company] also recognizes and respects basic trade union rights covering freedom of association, right to organize and the right to engage in collective bargaining. (PapCorpSE GFA)

In contrast, ConCorpSE stresses that "employee rights to form or join trade unions shall be recognized in accordance with each respective country's laws and principles" (ConCorpSE GFA). The RubberCorpDE GFA, in addition to adhering to ILO standards, stresses the functionality of good LR for long-term economic success:

Confidence and cooperation between management, employees and their representatives, innovation and flexibility in work organization are the basis for the employees' future success and that of [the company]. (RubberCorpDE GFA)

BuildCorpDE merely lists eight labor standards as bullet points.

\section{Scope}

The major issue regarding scope is whether, in addition to the direct operations of the respective MNE, the agreement also covers entities in which it is a majority/minority shareholder and also covers suppliers and contractors or subcontractors. Here the PapCorpSE agreement is relatively weak but specific:

This agreement covers all activities where PapCorpSE has direct control. Where PapCorpSE does not have direct control, it will exercise its best efforts in order to secure compliance with the standards set out in this agreement. (PapCorpSE agreement) 
The ConCorpSE agreement extends to all subsidiaries but only in a weaker form to contractors and subcontractors. Similarly, RubberCorpDE has restricted the agreement to those entities in which it has management prerogative, seeking to exclude joint ventures, the most important of which is in the United States. Additionally, the agreement applies only to direct employees. BuildCorpDE, in contrast, states that the ILO standards should also apply to all contractors and subcontractors.

[BuildCorpDE] acknowledges that it . . . also shares responsibility for the conditions under which the employees of its contractual partners do their work. (BuildCorpDE agreement)

\section{Procedural Rules}

Despite its narrower scope, the PapCorpSE agreement stands out in its detailed procedures for handling the agreement. The parties use a "review meeting" among management and labor representatives that occurs every two years, and a formal complaint-handling procedure is specified. ConCorpSE also has a formal complaints procedure involving a reference group that meets twice a year, consisting of representatives from ConCorpSE central management, a committee of the EWC, a GUF representative, and a representative from the union at the HQ. The complainthandling process includes formal arbitration, which is still an exception among GFAs.

In contrast, RubberCorpDE's procedure for handling complaints remains unspecified in the agreement except for a reference to annual meetings and ad hoc communication between management and union representatives. Even more informally, BuildCorpDE complaints are tackled case by case, and management assumes general authority for devising appropriate measures to deal with reported violations.

\section{GFA Implementation}

The relations between PapCorpSE and the relevant U.S. union were quite contentious during the late 1990s and early 2000s but improved as a result of a national agreement negotiated in the shadow of the 2004 GFA. According to the national union leader managing the relations with PapCorpSE, the GFA, combined with the national agreement, facilitated the unionization of a plant in Arizona, a right-to-work state, in 2007 as well as the negotiation of a 2009 collective agreement in a New York location. While local managers in these and other sites acquired by the company are still learning how to adjust to more collaborative LR, the relations in the company's only "greenfield" investment, also in a right-to-work state, are described as being as collaborative as those in Sweden. The U.S. union and PapCorpSE also established a joint advisory committee to ensure compliance in all its unionized sites. At the same time, two cases demonstrate the challenges of LR translation in the face of local LR. One plant is not 
covered by the national agreement, although it is not located in a right-towork state. According to HQ management,

[Our] factories in the U.S. are all unionized. But this part is not. . . That's not ... [because] they're not allowed. We have the same practices all over. We will of course welcome unions, but it has to come from the people. (PapCorpSE HQ HR manager)

Unionists explained that the company adheres to high standards there and that the limited number of workers (about 160) makes an organizing drive daunting.

Another plant is nonunionized despite being located in a highly unionized state. This site is used by the U.S. union as a test case to petition the NLRB for the certification of a minority union. Minority unions-those that represent only their members-have not had legal standing under U.S. labor law, an interpretation that this ongoing legal case is challenging. This PapCorpSE site and case might bring about a foundational change in U.S. LR, provided that the case survives the federal court system.

ConCorpSE's record of collective LR in the United States is less profound than PapCorpSE's, but over time the settling of disputes and the establishment of a regular dialogue involving U.S. unions and management indicate that a translation is taking place. Local management in the United States has tended to be more reactive than proactive, catalyzing interventions from the HQ:

There have been a couple instances where [ConCorpSE HQ] had to step in and talk to the local management, explain to them, look, you need to have a more cooperative attitude towards unions, what are you scared of and what is the problem? (GUF representative for ConCorpSE)

In one case, global management joined the GUF in bringing the local unions and the local management together in regular talks about national issues after a dispute in Florida escalated into a union campaign against the company. Florida, a right-to-work state, is particularly problematic:

It is a complicated situation. They have very weak labor rights and, frankly, we have got weak coverage there, so we have to expand. We have to work with trade unions not affiliated, so we really need to try and broaden our coverage with all the buildings trades in the U.S. if we want to make the agreement more meaningful there. (US Union BWI representative)

HQ management also intervened at a ConCorpSE facility in California where local management had refused to bargain in an attempt to change an existing agreement. The president of the home union urged central management to intervene, and ConCorpSE reacted by sending a delegation. The home union plays an important role in intervening with HQ management, either directly or through the BWI, thus brokering transnational union collaboration. The U.S. unions appreciate the support they get from the Swedish union. 
In a proactive move, BWI organized a meeting involving ConCorpSE, BuildCorpDE, and host country unions to institutionalize a process of GFA implementation in 2006. ConCorpSE's U.S. management was not enthusiastic, but under pressure from HQs and home country unions, it has slowly moved in the direction of dialogue. Beginning in 2011, U.S. management has agreed to annual meetings, the first of which took place in 2012. These meetings also involve visits to worksites. More recent (2015) information affirms that these meetings continue and that the GFA is being renegotiated to take into account U.S. LR.

These developments contrast with the situation at BuildCorpDE. A participant told us that the host country CEO acted as if he had never heard of the GFA at the 2006 meeting, leading the global CEO to remind him of the commitment. Generally, however, the global HQ is less willing to impose its wishes on key subsidiaries than ConCorpSE. In fact, interviewees on the labor side often referred to phone calls as the most effective means to communicate with management about alleged violations.

I don't know what you expect about how things work in corporations. We get contacts via the Geneva organization [i.e., the GUF] and via the national union. The national union also has a network within their union federation. Someone will hear something. These instances will then be collected and solved. (BuildCorpDE supervisory board employee representative)

This corporate attitude is reinforced by the fact that all labor representatives at BuildCorpDE repeatedly stress the harmonious, informal way in which the GFA is used, underscoring how deeply labor actors at BuildCorpDE are absorbed into comanagement. According to a U.S. union representative, the German union and the works council are much more reluctant to connect directly with U.S. unions than are the Swedish unions at ConCorpSE.

RubberCorpDE emphasized from the beginning that it would not export German LR and that it sought to adhere to host country LR institutions. This approach led to pronounced conflicts during the late 1990s, just before the GFA was signed, when the company purchased a unionized plant covered by a collective agreement and sought to avoid communication with the union as well as its obligations under the collective agreement. Subsequently, the GFA was an important tool for local unions to put pressure on RubberCorpDE to respect the collective agreement in that plant and in trying to organize another plant, but local management actively resisted the GFA:

I do recall when the trade unions came knocking . . because RubberCorpDE had signed this agreement. That should give them free access to our associates and an open door policy. And that open door policy doesn't really exist in the U.S. (RubberCorpDE U.S. subsidiary management)

Instead, the GFA did not prevent global and U.S. management from avoiding meaningful dialogue: 
In the U.S., it is more like that the management would not even have talked to us about a different behavior towards local organizing activities without this agreement. That's very clear. From time to time, the HQ management signals that the agreement should be interpreted differently in the U.S. Because RubberCorpDE was the only company with such an agreement and none of the U.S. companies had signed such an agreement. (RubberCorpDE EWC representative)

Despite the initial unwillingness of both global and U.S. management to adhere to the GFA, the collaboration of U.S. and Canadian unions with the ICEM forced global management to acknowledge its obligations and participate in a meeting in 2008 between management and unions where they agreed to amend the GFA through the inclusion of explicit neutrality language. However, later developments documented in the NLRB cases database suggest that neutrality is not necessarily observed on the ground. In its effort to defeat a 2013 unionization vote in one of its Ohio plants, U.S. management asked the NLRB to count votes by summer interns. The union won the vote, but the attitude of the subsidiary's management sheds some light on problems with adequate translation of collective representation practices.

Table 3 summarizes our key findings.

\section{Discussion and Conclusion}

Our findings on the dynamics engendered by GFAs in four European MNEs allow us to elaborate on how institutions, interests, and identities of actors at different levels influence the translation of collective representation practices into the United States. Overall, Swedish unions seemed more equipped than German ones to push for a stronger agreement and involved themselves more directly in making the GFA operative in the United States. Our analysis suggests that the different LR institutions in the two home countries provided management and labor actors with different opportunity structures to weaken or strengthen a GFA. This finding also adds to our existing knowledge on the success of GFAs in the United States and the role of foreign MNEs for U.S. LR more broadly.

First, in both German cases labor actors had a comparatively weaker influence on the GFA because management could choose its preferred partner, shifting from the works councils to the union level in RubberCorpDE and holding the GUF at bay by privileging home country unions and works councils in BuildCorpDE. A dual representational system thus gives management some flexibility to choose those partners who are more inclined to act in accordance with its interests. Swedish unions, in contrast, had a strong influence over management in both cases and actively involved the GUFs.

Second, the national unions in both countries had a different attitude toward the GFA, with Swedish unions appreciating the formal "bite" of the agreements vis-à-vis unilateral CSR activities and German unions keeping 


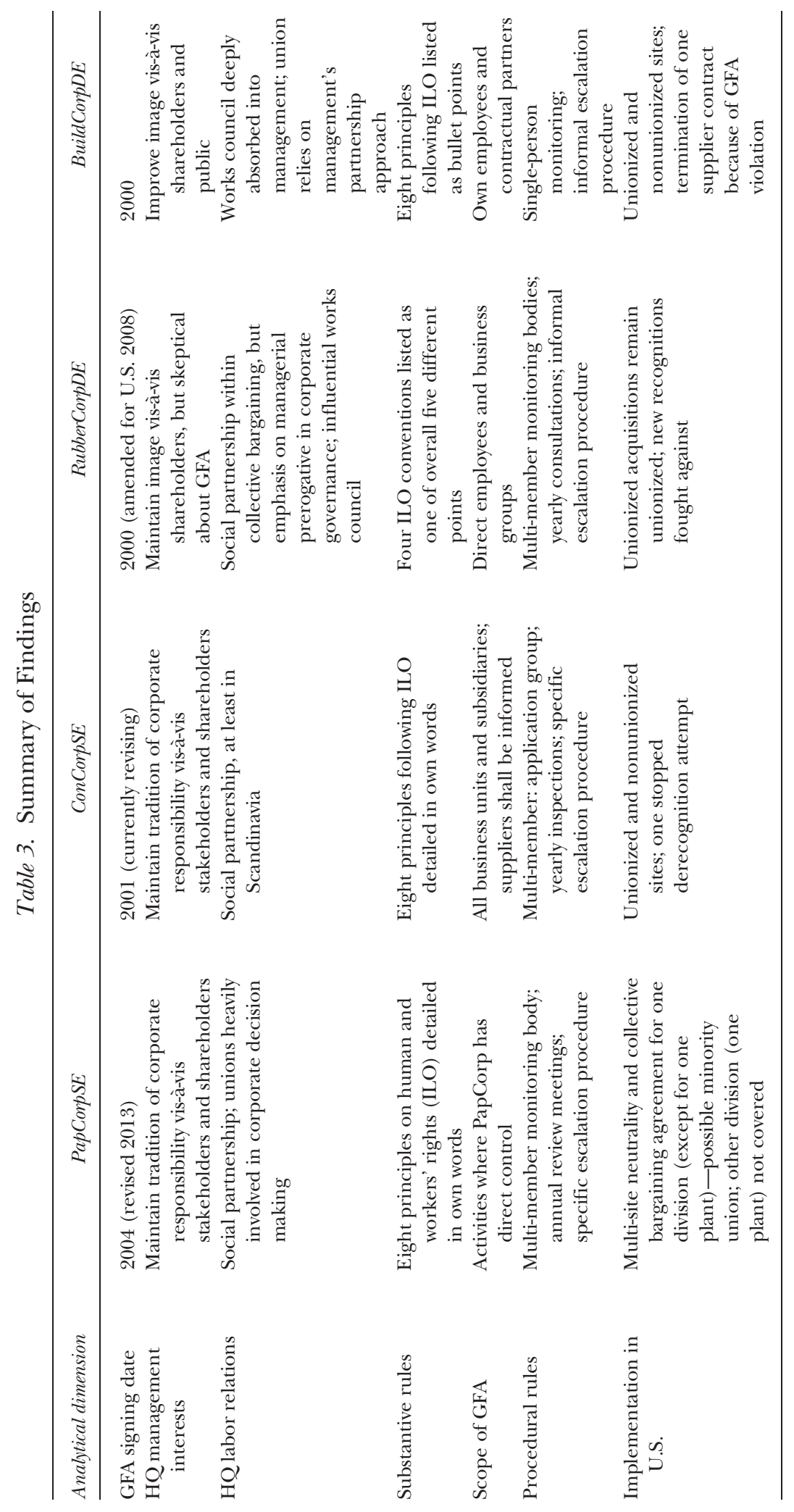


the GFA relatively informal, in line with existing CSR systems. Again, this difference points toward the salience of different home country LR. Operating within the dualistic system, German unions are more reluctant to bring global unions into the GFA processes within MNEs to avoid jeopardizing the complex balance of power among HQ-level management factions, influential works councils, and themselves. The dualistic German system is thus difficult to translate into a monistic system such as that in the United States not only because of institutional incompatibilities but also because of power relations at the HQ level. Again, this finding supports the salience of actors' interests and identities in transfer processes (e.g., Geppert and Dörrenbächer 2014).

Third, compared with the two Swedish unions, German unions took a rather passive approach toward international solidarity. One explanation is that Swedish unions strive to foreclose a "reverse diffusion" (Edwards, Almond et al. 2005) of weaker practices back to Sweden and act proactively. Another explanation might be that new transnational institutions and actors add further complexities to the dualistic LR in Germany and are thus evaluated more critically than in Sweden (for a similar argument regarding EWCs see Marginson, Lavelle et al. 2013). Finally, this pattern might be indicative of Germany's gradual move from a coordinated to a dualistic market economy (e.g., Streeck 2009; Palier and Thelen 2010).

Home country LR institutions do not determine transfer processes, and additional factors need to be taken into consideration. First, HQ management's commitment to labor rights and an open dialogue with unions may develop independently of whether the LR system is dualistic or monistic. Some German firms, such as Volkswagen, are actively trying to translate their LR style into the United States but face strong local resistance. Conversely, not all Swedish signatories of GFAs are active promoters of collaborative LR. IKEA, for instance, is generally not a union-friendly company, and it has continued this approach in the United States (Vail 2012). Even in this scenario, however, collaboration between the U.S. woodworking union, its Swedish counterpart, and the BWI resulted in union certification in the U.S. facility of the company's woodworking division, Swedwood, demonstrating the influence of Swedish unions.

Second, the Swedish MNEs we examined do not have an equally strong implementation record in other countries such as Colombia and Russia, where the opportunities to collaborate with local unions are more limited (Helfen, Schüßler, and Botzem 2015). Likewise, host country unions need to coordinate their initiatives with each other and with additional transnational actors to put GFAs into effect (see also McCallum 2013) so that their position mediates HQ strategies. Surprisingly, location in a right-to-work state in the United States did not affect GFA implementation in our cases.

Third, MNEs develop different organizational structures for coordinating product divisions or setting up regional headquarters independently from home country institutions. As our two Swedish cases with globally integrated 
product divisions indicate, these structures may influence the extent to which HQ management supports the translation of LR practices. However, whether more decentralized structures pose actual constraints on management's capacity to implement GFAs or whether they strategically serve to support a hands-off approach needs to be explored in further research. In the case of RubberCorpDE, for instance, the company exerts a direct influence on LRs despite having decentralized product divisions. Additionally, as indicated by PapCorpSE, the translation of LR might also be occasionally easier in greenfield sites than in acquired ones if an MNE is committed to the GFA. If not, greenfield facilities are usually not easy to unionize, as the practices in RubberCorpDE's joint venture show.

Fourth, against our initial expectations we did not observe sectoral differences, although the companies in the construction and consumer goods sector share several similarities and the two GUFs are associated with different global strategies. GUFs, however, cover several sectors and many different unions, and our cases indicate that their strategies are adapted to a given situation. ICEM, for instance, played an active role in forcing RubberCorpDE to formally recognize its GFA commitments in the United States, but it also could not prevent the company from marginalizing the more active works council. At PapCorpSE, ICEM largely followed the lead of U.S. and Swedish unions. The BWI generally took a softer approach, and yet both construction MNEs exhibit very divergent behavior. We interpret these findings as supporting our conjecture that more research is needed on the role of home country institutions as mediators of transnational LR initiatives.

Our findings have important implications for institutional analyses of transfer processes more generally. In particular, they reiterate that the macro-level perspective of the varieties of capitalism and institutional distance frameworks cannot always capture the range of more fine-grained firm-level dynamics, here, those affecting collective representation practices (Lamare et al. 2013). Hence, we would not generalize from our qualitative data that all German and Swedish MNEs will follow the patterns we identified. However, they indicate that different micro-political opportunity structures, here those ensuing from monistic versus dualistic LR systems in MNEs' home countries, are an important theoretical dimension to consider in further analyses of the dynamics evolving around the transnational transfer processes (see also Fichter and McCallum 2015).

Our data shed light on only a relatively short moment of the entire process around GFAs. However, short follow-up interviews for each case indicate that the trends we identified were continued. PapCorpSE updated and strengthened its GFA in 2013, and ConCorpSE is about to renegotiate its GFA with a specific eye on U.S. operations. No such activities are present in the German firms. Yet further research is clearly needed to elaborate on the differential impact of monistic and dualistic LR systems on transnational LR in other sectors and other host countries. 


\section{References}

[BDA] Bundesvereinigung der deutschen Arbeitgeberverbände. 2011. Neue Herausforderungen für globale industrielle Beziehungen: International Framework Agreements (IFAs) und Global Campaigning. Report. Berlin.

Behrens, Martin. 2009. Still married after all these years? Union organizing and the role of works councils in German industrial relations. Industrial and Labor Relations Review 62(3): 275-93.

Brewster, Chris, Geoff Wood, and Michael Brookes. 2008. Similarity, isomorphism or duality? Recent survey evidence on the HRM policies of MNCs. British Journal of Management 19(4): 320-42.

Bronfenbrenner, Kate. 2009. No holds barred. The intensification of employer opposition to organizing. EPI Briefing Paper. Washington, DC: Economic Policy Institute.

Brulin, Göran. 1995. Sweden: Joint councils under strong unionism. In Joel Rogers and Wolfgang Streeck (Eds.), Works Councils: Consultation, Representation, and Cooperation in Industrial Relations, pp. 189-216. Chicago: University of Chicago Press.

[BWI] Building and Wood Workers International. 2007. Guidance on International Framework Agreements (IFAs), approved by BWI World Council on 16 November 2007.

Colling, Trevor, Pappy Gunnigle, Javier Quintanilla, and Anne Tempel. 2006. Collective representation and participation. In Phil Almond and Anthony Ferner (Eds.), American Multinationals in Europe: Managing Employment Relations across National Borders, pp. 95-118. Oxford: Oxford University Press.

Compa, Lance. 2008. Labor's new opening to international human rights standards. Working USA: The Journal of Labor and Society 11(1): 99-123.

2012. Do international freedom of association standards apply to public sector labor relations in the United States? Accessed at http://digitalcommons.ilr.cornell.edu/arti cles/780 (May 18, 2015).

- 2014. When in Rome: The exercise of power by foreign multinational companies in the United States. Transfer: European Review of Labour and Research 20(1): 271-93.

Compa, Lance, and Fred Feinstein. 2012. Enforcing European corporate commitments to freedom of association by legal and industrial action in the United States: Enforcement by industrial action. Comparative Labor Law E Policy Journal 33(4): 635-65.

Cooke, William N. 2001. Union avoidance and foreign direct investment in the USA. Employee Relations 23(6): 558-80.

Cooper, Steve. 2012. Unions in a "death spiral"? Not on my job site: In the building trades labor is flourishing. Salon, February 20. Accessed at http://www.salon.com/2012/02/10/ unions_in_a_death_spiral_not_on_my_job_site/ (May 18, 2015).

Davies, Steve, Nikolaus Hammer, Glynne Williams, Rajeswari Raman, Claire S. Ruppert, and Lyudmyla Volynets. 2011. Labour standards and capacity in global subcontracting chains: Evidence from a construction MNE. Industrial Relations 42(2): 124-38.

Djelic, Marie-Laure, and Sigrid Quack (Eds.). 2003. Globalization and Institutions. Redefining the Rules of the Economic Game. Cheltenham, UK: Edward Elgar.

Dörrenbächer, Christoph, and Mike Geppert. 2006. Micro-politics and conflicts in multinational corporations: Current debates, re-framing, and contributions of this special issue. Journal of International Management 12(3): 251-65.

Dörrenbächer, Christoph, and Mike Geppert (Eds.). 2011. Politics and Power in the Multinational Corporation: The Role of Institutions, Interests and Identities. New York: Cambridge University Press.

Eaton, Adrienne E., and Jill Kriesky. 1998. Decentralization of bargaining structure: Four cases from the US paper industry. Relations Industrielles/Industrial Relations 53(3): 486-516.

Edwards, Tony, Phil Almond, Ian Clark, Trevor Colling, and Anthony Ferner. 2005. Reverse diffusion in US multinationals: Barriers from the American business system. Journal of Management Studies 42(6): 1261-86.

Edwards, Tony, Trevor Colling, and Anthony Ferner. 2007. Conceptual approaches to the transfer of employment practices in multinational companies: An integrated approach. Human Resource Management Journal 17(3): 201-17. 
Edwards, Tony, Paul Marginson, and Anthony Ferner. 2013. Multinational companies in cross-national context. Integration, differentiation and the interactions between MNCs and nation states. ILR Review 66(3): 547-87.

Edwards, Tony, Olga Tregaskis, David Collings, Patrice Jalette, and Lourdes Susaeta. 2013. Control over employment practice in multinationals: Subsidiary functions, corporate structures, and national systems. ILR Review 66(3): 670-95.

European Commission. 2013. Industrial Relations in Europe 2012. Luxembourg: Publications Office of the European Union.

- 2015. Database on transnational company agreements. Accessed at http://ec.europa .eu/social/main.jsp? catId=978\&langId=en (May 18, 2015).

Ferner, Anthony. 1997. Country of origin effects and HRM in multinational companies. Human Resource Management Journal 7(1): 19-37.

Ferner, Anthony, and Matthias Varul. 2000. "Vanguard" subsidiaries and the diffusion of new practices: A case study of German multinationals. British Journal of Industrial Relations 38(1): 115-40.

Ferner, Anthony, Phil Almond, and Trevor Colling. 2005. Institutional theory and the crossnational transfer of employment policy: The case of "workforce diversity" in US multinationals. Journal of International Business Studies 36(3): 304-21.

Ferner, Anthony, Phil Almond, Trevor Colling, and Tony Edwards. 2005. Policies on union representation in US multinationals in the UK: Between micro-politics and macroinstitutions. British Journal of Industrial Relations 43(4): 703-28.

Ferner, Anthony, Tony Edwards, and Anne Tempel. 2012. Power, institutions and the crossnational transfer of employment practices in multinationals. Human Relations 65(2): $163-87$.

Ferner, Anthony, Javier Quintanilla, and Matthias Varul. 2001. Country-of-origin effects, hostcountry effects, and the management of HR in multinationals: German companies in Britain and Spain. Journal of World Business 36(2): 107-27.

Fichter, Michael, and Jamie K. McCallum. 2015. Implementing global framework agreements: The limits of social partnership. Global Networks 15: S65-85.

Fichter, Michael, and Dimitris Stevis. 2013. Global Framework Agreements in a Union-Hostile Environment: The Case of the USA. Berlin: Friedrich-Ebert-Stiftung. Accessed at http://library .fes.de/pdf-files/id/10377.pdf (May 18, 2015).

Fichter, Michael, Dimitris Stevis, and Markus Helfen. 2012. Bargaining for corporate responsibility: The global and the local of framework agreements in the USA. Business and Politics 14(3): 1-31.

Frege, Carola M. 2003. Transforming German workplace relations: Quo vadis cooperation? Economic and Industrial Democracy 24(3): 317-47.

Geppert, Mike, and Christoph Dörrenbächer. 2014. Politics and power within multinational corporations: Mainstream studies, emerging critical approaches and suggestions for future research. International Journal of Management Reviews 16(2): 226-44.

Geppert, Mike, and Karen Williams. 2006. Global, national and local practices in multinational corporations: Towards a sociopolitical framework. International Journal of Human Resources Management 17(1): 49-69.

Hall, Peter A., and David Soskice. 2001. An introduction to the varieties of capitalism. In Peter A. Hall and David Soskice (Eds.), Varieties of Capitalism: The Institutional Foundations of Comparative Advantage, pp. 1-72. Oxford: Oxford University Press.

Hayden, Annette, and Tony Edwards. 2001. The erosion of the country of origin effect. A case study of a Swedish multinational company. Relations industrielles-Industrial relations 56(1): 116-40.

Hedlund, Gunnar. 1981. Autonomy of subsidiaries and formalization of headquarterssubsidiary relationships in Swedish MNCs. In L. Otterbeck (Ed.), The Management of Headquarters-Subsidiary Relations in Multinational Corporations, pp. 25-78. Aldershot: Gower.

Hegji, Alexandra. 2012. Federal Labor Relations Statutes: An Overview. Washington, DC: Congressional Research Service. 
Helfen, Markus, Elke Schüßler, and Sebastian Botzem. 2015. Legitimation strategies of corporate elites in the field of labor regulation: Changing responses to global framework agreements. Research in the Sociology of Organizations 43: 243-68.

Helfen, Markus, and Jörg Sydow. 2013. Negotiating as institutional work: The case of labour standards and international framework agreements. Organization Studies 34(8): 1073-98.

Hellmann, Marion F. 2007. Social partnership at the global level: Building and Wood Workers' International experiences with international framework agreements. In Verena Schmidt (Ed.), Trade Union Responses to Globalization. Geneva: International Labour Office.

Hogler, Raymond L. 2015. The End of American Labor Unions: The Right-to-Work Movement and the Erosion of Collective Bargaining. New York: Praeger.

Human Rights Watch. 2010. A Strange Case: Violations of Workers' Freedom of Association in the United States by European Multinational Corporations. New York: Human Rights Watch.

[ICEM] International Federation of Chemical Energy Mine and General Workers' Unions. 2010. ICEM World Conference for the Chemical Industries. Geneva: ICEM.

[ICFTU] International Confederation of Free Trade Unions. 2004. A Trade Union Guide to Globalisation. Brussels: ICFTU.

[ILO] International Labour Office. 2002. The International Labour Organization's Fundamental Conventions. Geneva: ILO.

- 2008. Freedom of association in practice: Lessons learned. Report of the directorgeneral, International Labour Conference 97th session. Report I (B). Geneva: ILO.

Ilsoe, Anna. 2012. The flipside of organized decentralization: Company-level bargaining in Denmark. British Journal of Industrial Relations 50(4): 760-81.

[IOE] Organisation of Employers. 2007. International Framework Agreements. An Employers' Guide. Geneva: IOE.

[ITC] International Training Centre of the International Labour Organization. 2010. Key issues for management to consider with regard to Transnational Company Agreements (TCAs). Lessons learned from a series of workshops with and for management representatives. Turin: ITC. Accessed at http://www.itcilo.org/en/community/news/tcas-final/ at_download/file (May 18, 2015).

[ITUC] International Trade Union Confederation. 2006. Programme of the ITUC. Adopted by the Founding Congress of the ITUC, 1-3 November 2006. Vienna: ITUC. Accessed at http://www.ituc-csi.org/IMG/pdf/Programme_of_the_ITUC.pdf (May 18, 2015).

Jackson, Gregory, and Richard Deeg. 2008. Comparing capitalisms: Understanding institutional diversity and its implications for international business. Journal of International Business Studies 39(4): 540-61.

Katz, Harry. 1993. The decentralization of collective bargaining: A literature review and comparative analysis. Industrial and Labor Relations Review 47(1): 3-22.

Katz, Harry, and Alexander Colvin. 2011. Employment relations in the United States. In Greg Bamber, Russell Lansbury, and Nick Wailes (Eds.), International and Comparative Employment Relations: Globalization and Change, pp. 62-87. Los Angeles: Sage.

Kjellberg, Andreas. 1998. Sweden: Restoring the model? In Anthony Ferner and Richard Hyman (Eds.), Changing Industrial Relations in Europe, pp. 74-117. Oxford: Blackwell Oxford.

Kostova, Tatiana. 1999. Transnational transfer of strategic organizational practices: A contextual perspective. Academy of Management Review 24(2): 308-24.

Lamare, J. Ryan, Patrick Gunnigle, Paul Marginson, and Gregor Murray. 2013. Union status and double-breasting at multinational companies in three liberal market economies. ILR Review 66(3): 696-722.

Marens, Richard. 2012. Generous in victory? American managerial autonomy, labour relations and the invention of Corporate Social Responsibility. Socio-Economic Review 10(1): $59-84$.

Marginson, Paul, Jonathan La Velle, Javier Quintanilla, Duncan Adam, and Rocio SanchezMangas. 2013. Variation in approaches to European Works Councils in multinational companies. ILR Review 66(3): 618-44.

McCallum, Jamie K. 2013. Global Unions, Local Power: The New Spirit of Transnational Labor Organizing. Ithaca, NY: Cornell University Press. 
Meardi, Guglielmo, Paul Marginson, Michael Fichter, Marcin Frybes, Miroslow Stanojevic, and András Tóth. 2009. Varieties of multinationals: Adapting employment practices in Central Eastern Europe. Industrial Relations 48(3): 489-511.

Morgan, Glenn, and Peer H. Kristensen. 2006. The contested space of multinationals: Varieties of institutionalism, varieties of capitalism. Human Relations 59(11): 1467-90.

Müller, Michael 1998. Human resource and industrial relations practices of UK and US multinationals in Germany. International Journal of Human Resource Management 9(4): 732-49.

Müller-Camen, Michael, Phil Almond, Patrick Gunnigle, Javier Quintanilla, and Anne Tempel. 2001. Between home and host country: Multinationals and employment relations in Europe. Industrial Relations Journal 32(5): 435-48.

Nergard, Kristine, Jon Erik Dolvik, Paul Marginson, Juan Arasanz Diaz, and Barbara Bechter. 2009. Engaging with variable pay: A comparative study of the metal industry. European Journal of Industrial Relations 15(2): 125-46.

Palier, Bruno, and Kathleen Thelen. 2010. Institutionalizing dualism: Complementarities and change in France and Germany. Politics E् Society 38: 119-48.

Papadakis, Konstantinos. 2011. Shaping Global Industrial Relations. The Impact of International Framework Agreements. Basingstoke, UK, and Geneva: Palgrave MacMillan /International Labour Organization.

Platzer, Hans-Wolfgang, and Torsten Müller. 2011. Global and European Trade Union Federations. A Handbook and Analysis of Transnational Trade Union Organizations and Policies. Oxford: Peter Lang.

Pontusson, Jonas. 1997. Between neo-liberalism and the German model: Swedish capitalism in transition. In Colin Crouch and Wolfgang Streeck (Eds.), Political Economy of Modern Capitalism: Mapping Convergence and Diversity, pp. 55-70. London: Sage.

Pries, Ludger. 2003. Emerging production systems in the transnationalisation of German carmakers: Adaptation, application or innovation? New Technology, Work and Employment 18(2): 82-100.

Pudelko, Markus, and Anne-Wil Harzing. 2007. Country-of-origin, localization, or dominance effect? An empirical investigation of HRM practices in foreign subsidiaries. Human Resource Management 46(4): 535-59.

Riisgaard, Lone, and Nikolaus Hammer. 2011. Prospects for labour in global value chains: Labour standards in the cut flower and banana industries. British Journal of Industrial Relations 49(1): 168-90.

Rolfsen, Monica. 2013. Transfer of labour-management partnership in multinational companies. Industrial Relations Journal 44(3): 316-31.

Royle, Tony. 1998. Avoidance strategies and the German system of co-determination. International Journal of Human Resource Management 9(6): 1026-47.

Sahlin-Andersson, Kerstin, and Lars Engwall. 2002. The Expansion of Management Knowledge. Stanford, CA: Stanford University Press.

Schmitt, John, and Alexandra Mitukiewicz. 2012. Politics matter: Changes in unionisation rates in rich countries, 1960-2010. Industrial Relations Journal 43(3): 260-80.

Shimabukuro, Jon O. 2012. The National Labor Relations Act: Background and Selected Topics. Washington, DC: Congressional Research Service.

Stevis, Dimitris, and Terry Boswell. 2008. Globalization and Labor: Democratizing Global Governance. Lanham, MD: Rowman and Littlefield.

Streeck, Wolfgang. 2009. Industrial relations today: Reining in flexibility. Economics, Management and Financial Markets 4(3): 15-36.

Sydow, Jörg, Michael Fichter, Markus Helfen, Kadire Zeynep Sayim, and Dimitris Stevis. 2014. Implementation of global framework agreements: Towards a multi-organizational practice perspective. Transfer 20(4): 489-503.

Tempel, Anne, Tony Edwards, Anthony Ferner, Michael Müller-Carmen, and Hartmut Wächter. 2006. Subsidiary responses to institutional duality: Collective representation practices of US multinationals in Britain and Germany. Human Relations 59(11): 1543-70.

Tempel, Anne, and Peter Walgenbach. 2007. Global standardization of organizational forms and management practices? What new institutionalism and the business-systems approach can learn from each other. Journal of Management Studies 44 (1): 1-24. 
Thelen, Kathleen. 1993. West European labor in transition: Sweden and Germany compared. World Politics 46(1): 23-49.

Vail, Bruce. 2012. Machinists rapidly unionizing Ikea warehouses: 3 down, 2 to go. In These Times. Accessed at http://inthesetimes.com/working/entry/14275/machinists_union_ scores_new_victories_in_ikea_warehouse_organizing_campaign (May 18, 2015).

Wessels, Sherman. 2013. Collective bargaining in an era of union decline. Accessed at http://www.w-p.com/CM/Articles/Collective-Bargaining-in-Era-of-Union-Decline.asp (May 18, 2015). 
Copyright of Industrial \& Labor Relations Review is the property of Cornell University and its content may not be copied or emailed to multiple sites or posted to a listserv without the copyright holder's express written permission. However, users may print, download, or email articles for individual use. 